\title{
LITHOFACIES-GENETIC CHARACTERISTICS OF SEDIMENTARY BASINS IN THE FORELAND OF THE POMERANIAN STAGE IN THE DRAWSKO LAKELAND (NORTHERN POLAND)
}

\author{
Ryszard Paluszkiewicz, Renata Paluszkiewicz \\ Adam Mickiewicz University, Instytute of Geoecology and Geoinformation, Poznań, Poland
}

Manuscript received: May 21, 2011

Revised version: September 3, 2011

\begin{abstract}
Paluszkiewicz R., Paluszkiewicz R., 2011. Lithofacies-genetic characteristics of sedimentary basins in the foreland of the Pomeranian Stage in the Drawsko Lakeland (northem Poland). Quaestiones Geographicae 30(3), Bogucki Wydawnictwo Naukowe, Poznań, pp. 61-69, 7 Figs. ISBN 978-83-62662-75-3. ISSN 0137-477X. DOI 10.2478/ v10117-011-0027-8
\end{abstract}

AвSTRACT. The research carried out in the years 1995-98 in the area of the Złocieniec proglacial lake inclined its authors to take a broader view of the operation of proglacial basins in the Drawsko Lakeland (Paluszkiewicz 2004). Glaciolacustrine deposits in the studied lakeland area were discovered by Maksiak and Mróz in 1978. Until that time, the varved deposits at Złocieniec had not been subjected to lithological analysis. The more detailed studies conducted by the present authors in the years 2006-2007 at both Złocieniec and Wierzchowo sites with the help of geo-engineering methods allowed them to show that the two sites with varved clays in this region should be treated as separate sedimentary basins. The basins differ in thickness of varved deposits, in size, and processes responsible for the formation of the rhythmically stratified series.

KEYWARDS: proglacial lake, varved clays, glaciolacustrine deposits, Drawsko Lakeland, Pomerania

Ryszard Paluszkiewicz, Renata Paluszkiewicz, Adam Mickiewicz University, Instytute of Geoecology and Geoinformation, Dzieggielowa 27,61-680 Poznań,Poland; e-mail:paluch66@amu.edu.pl, reniach@amu.edu.pl

\section{Introduction}

Geological studies carried out by Maksiak and Mróz in the 1970s in West Pomerania revealed an extensive proglacial basin in the Złocieniec and Wierzchowo area.

In the years 1995-1998 researches were carried out in the Złocieniec region to establish the conditions of sedimentation of rhythmically stratified, varved deposits (Paluszkiewicz 2004). On the basis of an analysis of a N-S ori- ented series of boreholes, both archival and the researcher's own, it was found that between the glaciolacustrine clays of the Złocieniec area and those of Wierzchowo there was a transition zone where glaciolacustrine deposits passed into fluvioglacial ones represented by sands (Fig. 1). The research made possible to state that the area of clays around the town of Wierzchowo could be a separate proglacial basin.

In the years 2006-2007 a research was made under grant no. 0562/PO4/2005/29 concerning 
a possible use of the static cone penetration test (CPTU) to analyse the stratigraphy of Cainozoic deposits (Wierzbicki et al. 2007). The study area included also the Złocieniec and Wierzchowo proglacial lakes (the Drawsko Lakeland). That allowed the researchers to make a detailed characterisation of the deposits filling the Wierzchowo (Wierzbicki et al. 2011) and the Złocieniec basins (Paluszkiewicz et al. 2007).

The aim of this paper is to present the lithogenetic dissimilarity of the Złocieniec and $\mathrm{Wi}$ erzchowo proglacial lakes, and thus to show that they should be considered as separate sedimentary basins.

\section{Study area}

In terms of the physical-geographic division of Poland (Kondracki 1988), the Złocieniec and Wierzchowo proglacial lakes lie within the Drawsko Lakeland, which is a part of the West Pomeranian Lakeland (Fig. 1).

According to Maksiak and Mróz (1978), the Drawsko Lakeland can be divided into two parts:

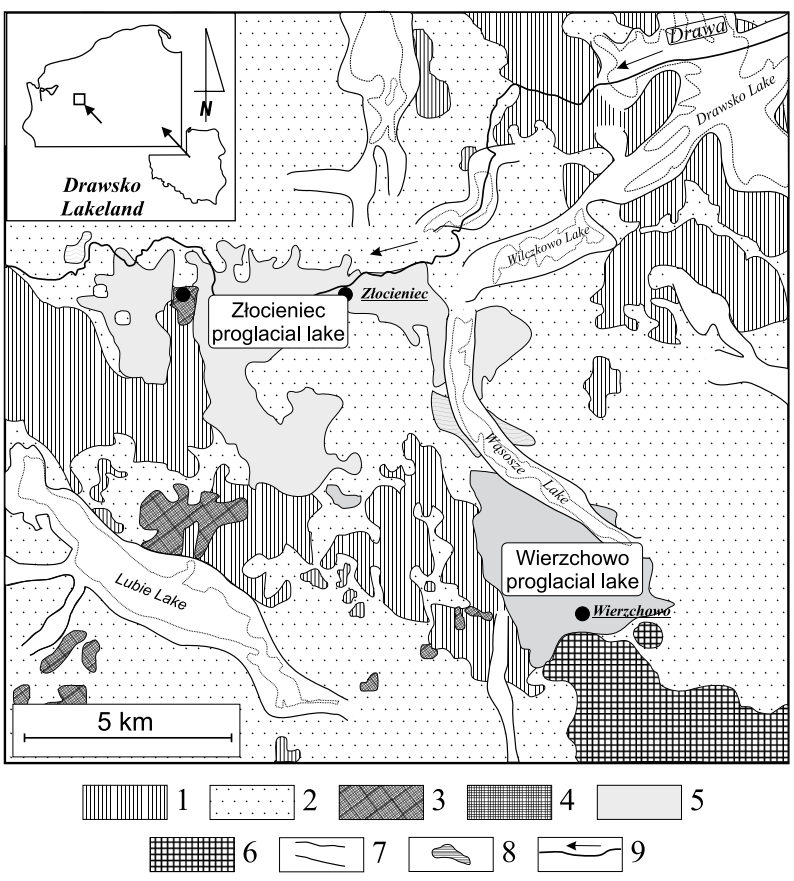

Fig. 1. Location of the study area of the geomorphological situation.

1 - till belonging to the Pomeranian Phase, 2 - glacifluvial sands and gravels, 3 - end moraines of the Pomeranian Phase maximum extent, 4 - recession end moraines, 5 - glacial lakes areas, 6 - areas of the Pre-Pomeranian Phase, 7 - glacial troughs, 8, 9 - lakes and rivers. an inner (northern) and an outer (southern) one. The areas investigated in the present study are situated in the southern part. The inner part of the lakeland is highly diversified in morphological terms (altitudes ranging from 100 to 238 $\mathrm{m}$ a.s.l.) since it is occupied by a postglacial plateau built mostly of till. The boundary between the northern and the southern part is formed by a line of end-morainic hills often exceeding 200 $\mathrm{m}$ a.s.l. In the opinions of Keilhack $(1901,1930)$, Galon and Roszkówna (1967), Karczewski (1985, 1994) and others, this was the zone of the maximum extent of the Pomeranian Stage of the Baltic Glaciation. According to the above authors, the Złocieniec and Wierzchowo proglacial lakes are situated in the foreland of this stage.

In the outline of the proglacial lake around the localities of Złocieniec and Wierzchowo presented in Fig. 1, one can find extensive glaciolacustrine plains. Occupying a nearly flat surface, they are bounded from the south by end moraines forming a line starting east of Kalisz Pomorski and extending through Orla - Żabinek - south of Czaplinek and Liszkowo - Krągi Turowo - Gwda Wielka - Brzezie to Pieniążnica. In the opinions of Maksiak and Mróz (1978) and Kłysz (1990, 1998), it is this line that marks the maximum extent of the inland ice of the Pomeranian Stage, which means that the proglacial lake formed in its hinterland.

\section{Present state of knowledge about the occurrence of varved deposits in the Drawsko Lakeland}

On the maps by Keilhack (1901, 1930, Fig. 2, Fig. 3), which provide a source material for more recent works concerning the Drawsko Lakeland, the area of occurrence of glaciolacustrine deposits is not marked at all. On the 1901 map (Fig. 2), is marked on the place of proglacial lake there is a zone of outwash plains which borders a ground-morainic plateau in the south. On the 1930 map, in turn (Fig. 3 ), this area is occupied by a morainic plateau built of till, which passes into a zone of outwash plains in the south. In none of those cartographic works does the author indicate any proglacial lake.

The next researchers: Pietkiewicz (1947), Galon (1947), Bartkowski (1965, 1972), Augustowski 


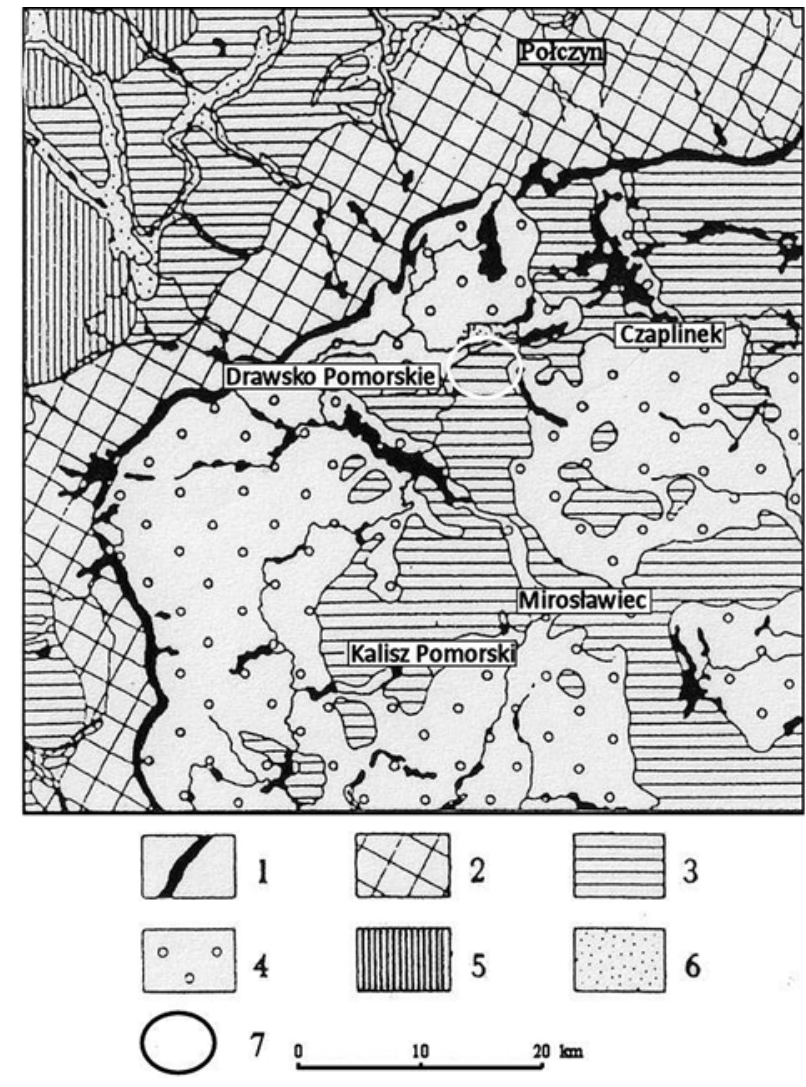

Fig. 2. Pomeranian Phase ice - sheet marginal zone in the Drawsko Lakeland - Keilhack (1901)

1 - end moraine, 2 - hummocky moraine, 3 - ground morainic plateau, 4 - glacial outwash, 5 - drumlin field, 6 - valley floors, 7 study area.

(1977), and Kondracki (1988), probably rely in their work on that of Keilhack. Pietkiewicz (1947) shows the Drawsko Lakeland to lie in the central part of the Pomeranian Lakeland. As in Keilhack's earlier cartographic works, also here we find outwash deposits in place of glaciolacustrine ones. In turn, when characterising the Pomeranian Lakeland, Augustowski (1977) marks numerous end-morainic and kame hills as occurring near Złocieniec.

On a general-reference geomorphological map of Poland (the Poznań sheet) edited by Rosa and Kozarski (1986), in place of a fossil proglacial basin there is a hilly marginal zone bounded from the south by ridges of push moraines (Fig. 4). In the north-east, this area borders a zone of outwash plains.

The first reports of glaciolacustrine deposits in the Złocieniec region appear in the early 1950s with the identification of a clay mineral deposit by the Złocieniec Structural Clay Products Factory.
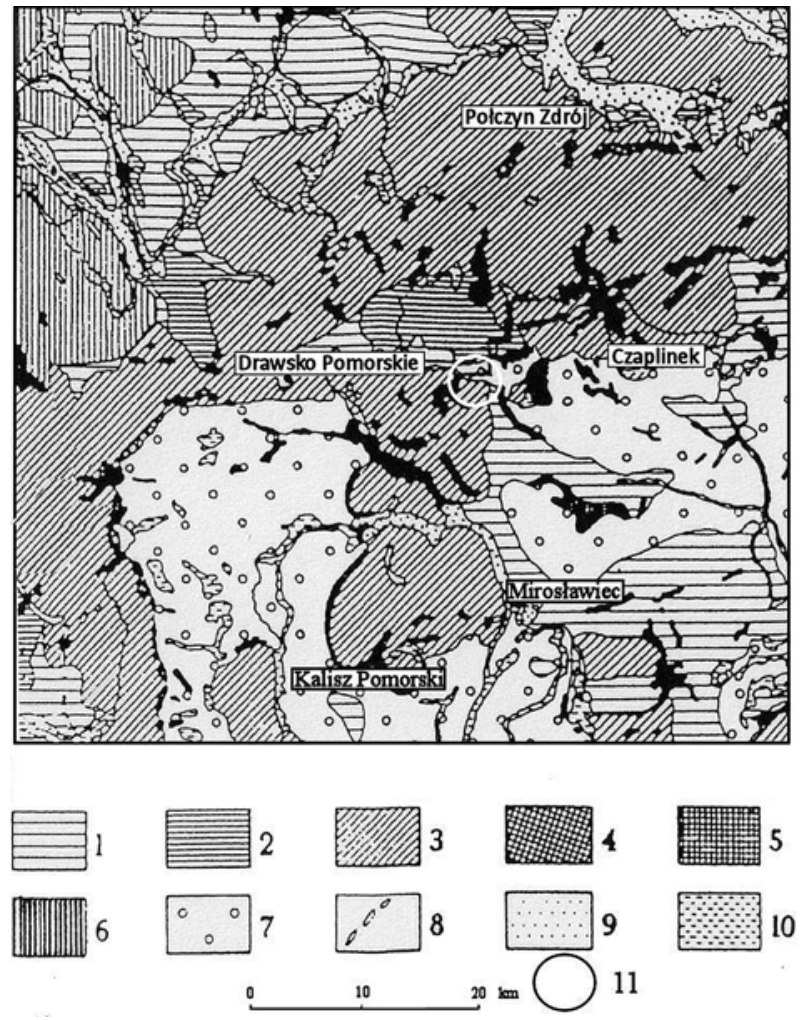

Fig. 3. Pomeranian Phase ice - sheet margispenal zone in the Drawsko Lakeland - Keilhack (1930)

1 - morainic plateau (till), 2 - morainic plateau (sands and gravels), 3 - hummocky moraine, 4 - block end moraine, 5 - push end moraine, 6 - drumlin field, 7 - glacial outwash, 8 - eskers, 9 - valley floors, 10 - peaty plains, 11 - study area.
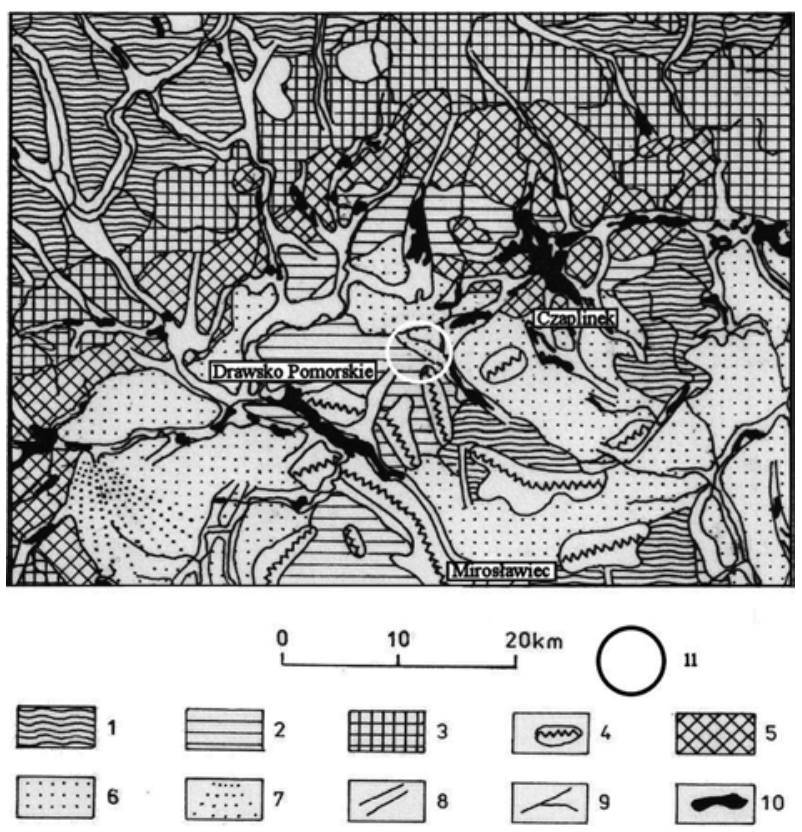

Fig. 4. Pomeranian Phase ice - sheet marginal zone in the Drawsko Lakeland (Rosa, Kozarski 1986).

1 - undulated ground morainic plateau, 2 - flat ich, 3 - hummocky marginal zone, 4 - push moraine ridges, 5 - accumulation morain ridges, 6 - outwash plains, 7 - outwash cownes, 8 - subglacial

chanels (lakes), 9 - rivers, 10 - lakes, 11 - study area. 
An outline of the boundaries of the Złocieniec proglacial lake was presented by Maksiak and Mróz in their 1978 publication. The geological and cartographic work they conducted in the central part of the Pomeranian Lakeland in the years 1971-1974 allowed them to assess the spatial extent and thickness of the region's glaciolacustrine deposits, including the Złocieniec area. An analysis of archival boreholes performed by the present authors showed the glaciolacustrine series at Złocieniec to have four levels represented by varved silts and clays, and from place to place by horizontally arranged fine-grained and silty sands. The thickness of glaciolacustrine deposits in the northern (proximal) part of the basin is considerable; in the opinion of the quoted authors, it can attain $31 \mathrm{~m}$ here. The thickness declines markedly towards the south. The authors explain this tendency to form glaciolacustrine levels by the location of the area in a zone without an outlet, in between well-established outflow routes coinciding with today's valleys of the rivers Gwda and Drawa.

The references in a later literature to rhythmically stratified deposits occurring in the Złocieniec or Wierzchowo area were only side notes in general-purpose works concerning the entire Pomeranian Lakeland made when explaining geomorphological issues (Kozarski 1986, Karczewski 1998).

An attempt to have a closer look at deposits filling the Złocieniec proglacial basin was made by Kłysz (1990). It was only a preliminary investigation (which, as the author himself stated, required a further, more detailed analysis). Apart from that, there were also several unpublished studies seeking to assess the properties of glaciolacustrine deposits, mostly of the Złocieniec area (Kubicka 1995, Polcyn 1995, Tuszyńska 1999, Jankowska 1999, Wilhelm 1999).

\section{The Złocieniec proglacial lake: geomorphological characteristics}

Within the boundaries of the proglacial lake determined by Maksiak and Mróz (1978), the ba$\sin$ in question occupies an area of about $26 \mathrm{~km}^{2}$.

The conditions of sedimentation in the Złocieniec proglacial lake were characterised by Paluszkiewicz (2004). On the basis of this research, several lithofacies complexes were distinguished there that had formed in the specific environmental conditions occuring at that time (Fig. 5). Deposits differ, in sedimentary structures in the nature of the dominating processes of transport and deposition (Paluszkiewicz 2004). From the bottom up, there are mineral series that are evidence of basin deposition in the initial stage, represented by sandy series (Sh(r); complex C). They pass into typically glaciolacustrine varved series. The zone of varved deposition is the most extensive cyclothem in which the thickness of the dominant lithofacies $\mathrm{Fv}$ varies from 5 to $15 \mathrm{~m}$. Taking into consideration the thickness of light and dark laminae within the individual depositional cycles, the complex (B) can be divided into two subgroups, B1 and B2. The top part of glaciolacustrine series is formed by a layer of lightgrey, massive coarse silty clay or fine silt 0.34 to 2 $\mathrm{m}$ thick. It developed when the basin had disappeared (complex A; Paluszkiewicz 2004).

In 2007 the traditional field and laboratory analyses were complemented with geo-engineering studies involving static cone penetration tests. Their basic aims were to determine the relation between the rhythmically stratified series and the mineral substratum, and to establish whether the glaciolacustrine series were deposited in a single or several depositional cycles. The CPTU testing was performed in points coinciding with the sites of the earlier research (Zamkowa, Rzęśnica and Złocieniec; Paluszkiewicz 2004, Paluszkiewicz et al. 2007). The method allows an assessment of the geotechnical parameters of the substratum in its natural state, i.e. in the place where it occurs. This fact makes it possible to use the results of a CPTU study in an analysis of the mechanical strength and stress of non-lithified deposits (Mayne 2006; Młynarek, Wierzbicki 2007; Wierzbicki et al. 2008).

The obtained results helped to distinguish layers in the profiles under analysis which, by analogy with the results of the archival studies, were characterised as individual lithofacies. The guidelines when making correlations with the archival divisions and between the individual points were mainly mean values of the CPTU parameters as well as the occurrence of the given lithofacies in the research and archival profiles. In 


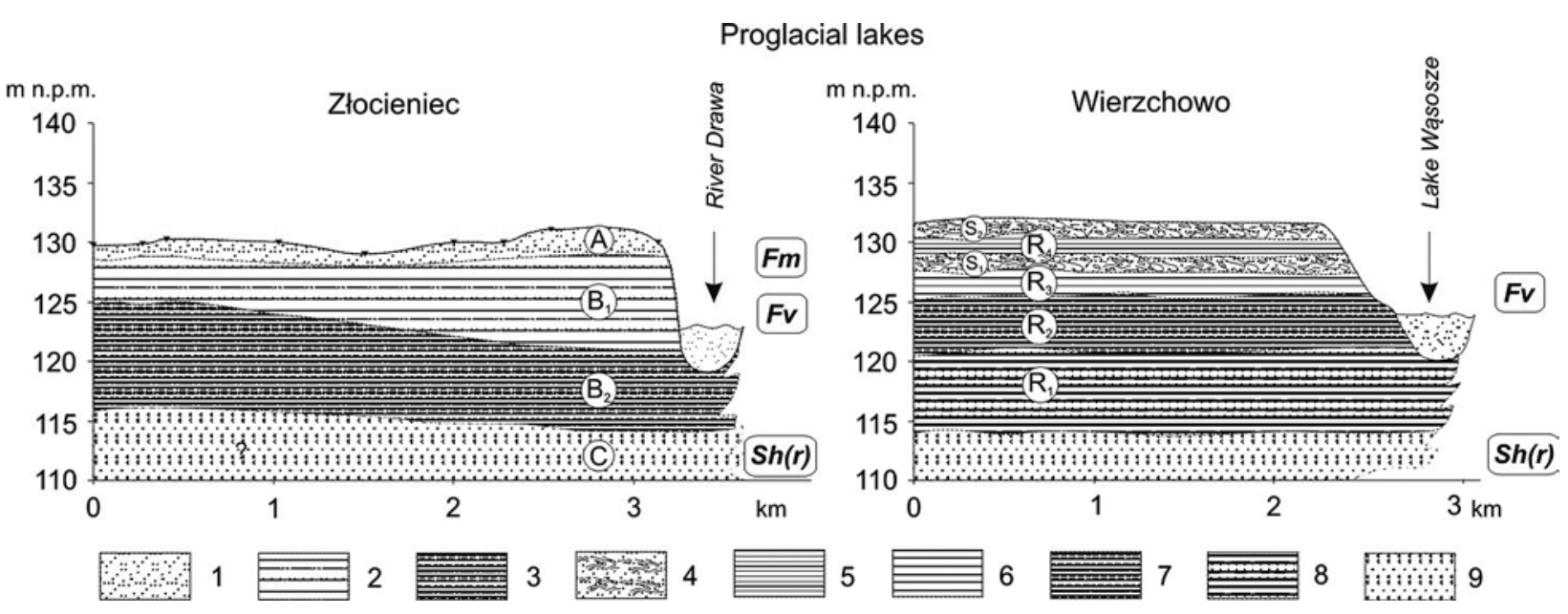

Fig. 5. The schematic model of deposits distribution in the Złocieniec and Wierzchowo proglacial lakes. 1 - massive mud, 2, 3 - silty clay (sequence varves), 4 - mud and silty clay (deformed laminae), 5, 6, 7, 8 - silty clay (sequence varves), 9 - silty sand (underlying, initial sediments).

effect, a picture of the geological structure of the substratum in the proximal part of the Złocieniec proglacial lake was obtained which confirms the archival analyses in a large extent.

In the case of the Zamkowa site, a very well marked division into lithofacies A, B1 and B2 is observed. While lithofacies B1 is a highly homogeneous group, B2 is composed of a complex of two intertwining groups. One of them has parameters typical for compact deposits (like typical varved clays), while the other contains deposits with a higher proportion of the sand fraction of the fine-grained type. Such characteristics of both lithofacies B obtained on the basis of CPTU testing coincide with the results of analyses carried out in exposures. An additional finding brought about by the geo-engineering method was the determination of the depth of lithofacies $C$ (the initial series in the glaciolacustrine basin underlying the varved series), that occurrence was impossible to document during earlier work.

At the two remaining sites (Złocieniec and Rzęśnica) there are some differences between the division from archival sources and that following from an analysis of the results of the geo-engineering studies. The arrangement of both 'extreme' lithofacies: A and C does not change; the differences concern a generally understood series of rhythmically stratified, varved deposits, i.e. lithofacies B. On the basis of the CPTU studies, this cyclothem was found to be more complex, requiring further divisions to be made in the profile. At Złocieniec, appeared a layer between lithofacies A and B1 that granulometric composi- tion corresponds to lithofacies B1, but which has markedly higher strength parameters. As well in the archival documentation, layers of glaciolacustrine deposits were found at a similar depth that differed from the underlying ones in their highly disturbed structure.

In the Rzęśnica profile, deposits were found at the bottom of the rhythmically stratified series that should be excluded from lithofacies B2 because they have a different granulometric composition and higher strength parameters. An analysis of those parameters obtained from the static cone penetration test showed that it was necessary to make additional divisions within complex B at Rzęśnica and distinguish lithofacies B3 to replace, in stratigraphic terms, the top part of lithofacies $C$ at the remaining research sites.

A very significant problem is to determine the directions of supply of mineral material to the proglacial basin. As follows from an analysis of structural measurements performed in the series of rhythmically stratified deposits, and especially from their general repetitiveness within the various sites, the predominant direction of supply was NW. The deposition of the mineral material also took place from the NE.

\section{The Wierzchowo proglacial lake: geomorphological characteristics}

To test the hypothesis put forward by Paluszkiewicz (2004) about separation of the two sedimentary basins, within the eastern part of the 


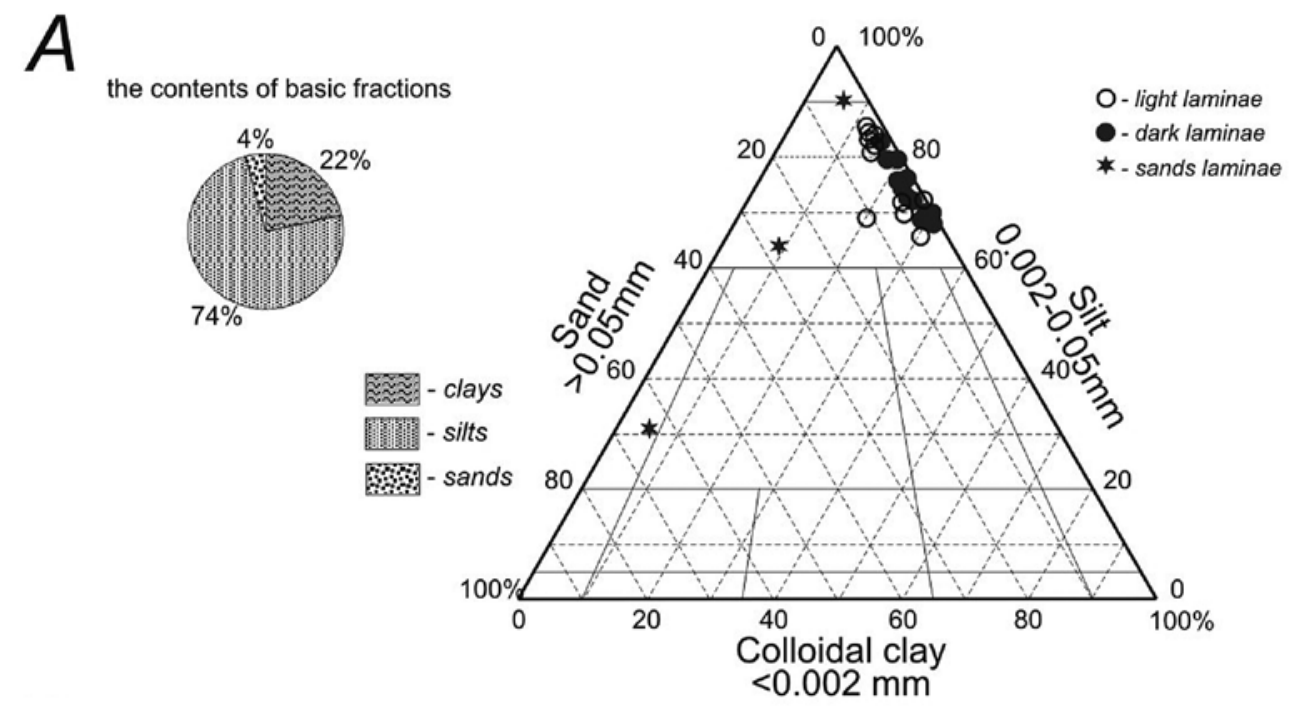

$B$

the contents of basic fractions
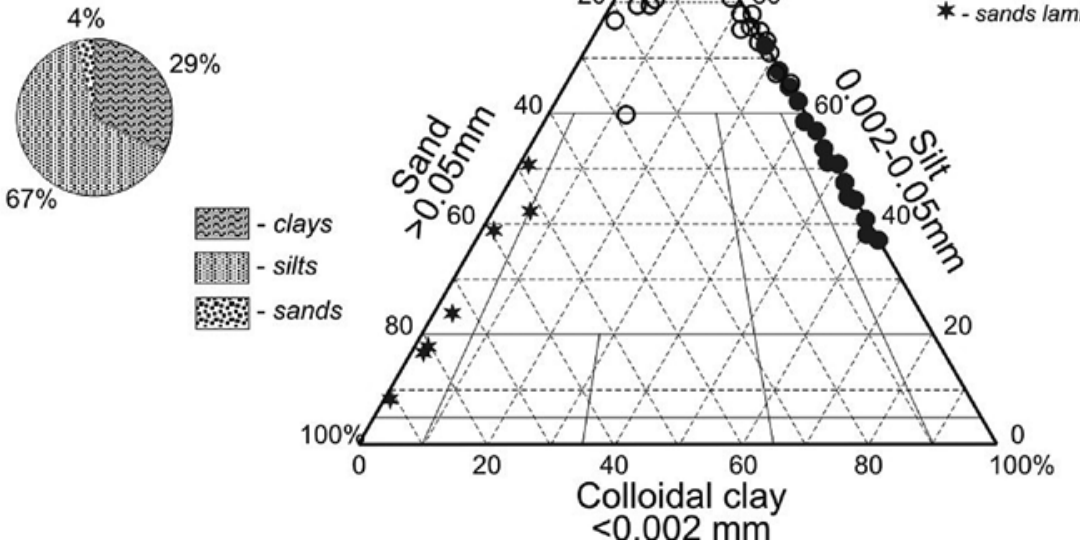

Fig. 6. Contents of basic fractions in studied profiles (A - Wierzchowo proglacial lake, B - Złocieniec proglacial lake).

Wierzchowo proglacial lake a research of similar range as previous was conducted and supplemented with geo-engineering analyses (Wierzbicki et al. 2011).

The Wierzchowo proglacial lake is located about $3 \mathrm{~km}$ SW of the Złocieniec proglacial lake. It's areais about $18 \mathrm{~km}^{2}$. A thorough study was made here in a disused mine outcrop, at a distance of some $2 \mathrm{~km}$ NE of Wierzchowo. The lithological characteristics of deposits were identified on the basis of hand-made drillings (Paluszkiewicz 2004) and an analysis of the borehole profiles and documentary materials prepared for the serie of glaciolacustrine deposits by the Geological and Construction Enterprise of the Aggregate and Mineral Raw Materials Industry (Gdańsk 1969).

According to the archival data, the thickness of the glaciolacustrine series in the Wierzchowo region does not exceed $10 \mathrm{~m}$. In the vertical profile of the research site, the series displays a bipartite structure separated into: varved clays and massive silts. The sedimentary sequence connected with the disappearance of the varved cycle in favour of massive deposits, together with an increase in the coarser fractions of the mineral grain towards the bottom, may be indicative of the basin shallowing.

A series of fine and medium-grained sands of fluvioglacial accumulation is lying under the rhythmically stratified, varved deposits is. The 
lowerings of the top of sands in some boreholes, according to the archival data, are filled with sandy, clay-rich silts that should be classified as belonging to the glaciolacustrine series.

A lithofacies analysis of the deposits of the Wierzchowo proglacial lake made on the basis of a 6-m-deep exposure made possible to distinguish four lithofacies complexes: S1, R1, S2, and R2 (Wierzbicki et al. - 2011, Fig. 5). In all of them there are clay and silt-clay series, rhythmically stratified, j.e. varved ( $\mathrm{Fv}, \mathrm{Fd}$;). The deposits of complexes S1 and S2 do not differ from the underlying varved series in granulometric terms. A characteristic feature of the deposits of those facies are the predominant flow structures similar to those described by Paluszkiewicz (2008); indicating of a high-energy environment. The architecture of deposits of complexes R1 and R2 is characteristic for rhythmically stratified series, with alternating dark and light laminae. Sporadically, there are discontinuous sand laminae within the R2 complex.

The lithofacies analyses were complemented with a geo-engineering study, of the CPTU test. Its results lead to the conclusion that within the examined fragment of the Wierzchowo basin there are at least four principal lithofacies reflecting the successive stages in the functioning of the basin, that confirms earlier the analyses. Lithofacies formfmation can be correlated with the filling stages of the sedimentary basin, starting with the initial, low-energy, varved stage (R2) through a high-energy stage (S2), then one of quiet varved deposition (R1), and finally again stage of, a heightened environmental energy involving the formation of the next zone of flow deformations (S1).

An analysis of the static cone penetration test allows an assumption that there were distinct interruptions between the individual stages of formation of the glaciolacustrine deposits, referring probably to erosional stages.

On the basis of the earlier study (Paluszkiewicz 2004) and the present one, it can be stated that the deposits of the Wierzchowo basin differ in their mode of formation from those of the Złocieniec one.

A detailed analysis of the varved series at Wierzchowo site and their comparison with the results obtained for the rhythmites of the Złocieniec proglacial lake show deposits to becomposed of series with coarser sediments (Fig. 6). In Wierzchowo site the number of depositional cycles involving the formation of varves does not exceed 110, in opposite to the Złocieniec basin in which the number of such cycles is greater than 380 (Fig. 7).

On the basis of the interpretation of sedimentary cycles of varves amount, it was assumed that the Złocieniec basin operated for at least 380 summer-winter seasons that convertrnally can be called 'years'. The glaciolacustrine basin in the Wierzchowo area functioned about 110 'years'.

The results of the laboratory examination of the deposits from both basins combined with the established lack of continuity of glaciolacustrine deposits between the two areas (Paluszkiewicz 2004) justify the statement that the two proglacial lakes functioned as separate depositional

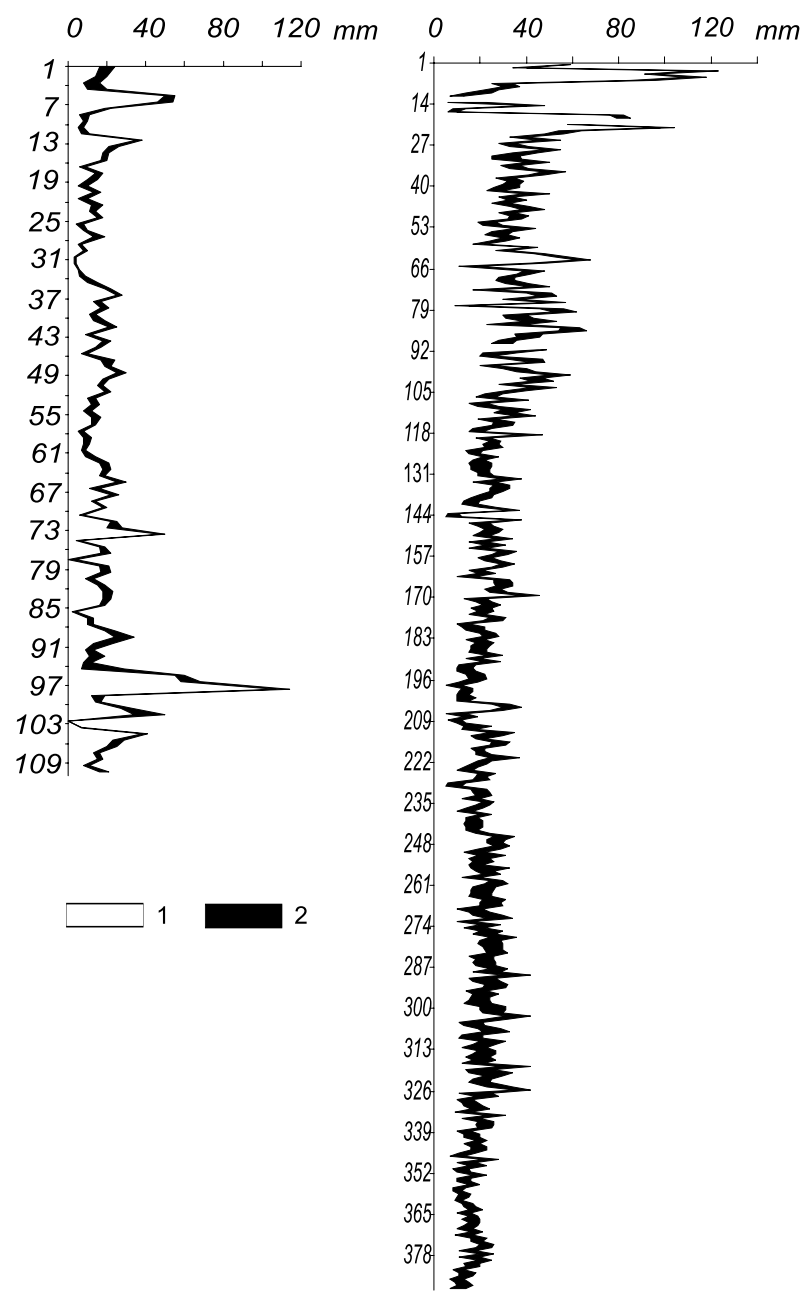

Fig. 7. Diagram of varves in studied profiles. 1 - light laminae, 2 - dark laminae. 
basins. Besides, while the general transport direction within the Złocieniec proglacial lake was from the north, the Wierzchowo lake (at least in its eastern zone) was nourished from the south, which means by extraglacial waters.

The more detailed work performed within both basins to assess the strength characteristics of deposits showed the basins to be different, which additionally supports the above supposed hypothesis (Wierzbicki et al. 2007; Wierzbicki et al. 2009).

\section{Conclusion}

On the basis of the results of the work conducted, both in the field and in the laboratory, it is possible to draw several conclusions of a general nature. Both investigated basins are of the proglacial type, with the Wierzchowo being once fed, at least periodically, by extraglacial waters. They show traces of the same set of processes responsible for deposits settling within the sedimentary basins (deposition of material from suspension and the activity of bottom currents). The differences involve the thickness of deposits and their mode of formation.

On the basis of the earlier research conducted by Paluszkiewicz (2004) in the area of the Złocieniec proglacial lake, another made within the Wierzchowo area, and the geo-engineering studies carried out within both sedimentary basins, it can be stated that the deposits of the Wierzchowo basin differ in their mode of formation from those of Zlocieniec. The lack of continuity of glaciolacustrine deposits between the two areas (Paluszkiewicz 2004) justifies the statement that the two proglacial lakes were separate depositional basins. The basic difference between their deposits is the thickness of the rhythmically stratified series. The varved series within the Złocieniec proglacial lake attain about $12 \mathrm{~m}$, while the $\mathrm{Wi}$ erzchowo rhythmites have thicknesses of up to several metres. A detailed analysis of the varved series and their comparison with the results obtained for the rhythmites of the Złocieniec proglacial lake showed the Wierzchowo deposits to consist of series built with coarser sediments.

The more detailed work performed within both basins to assess the strength characteristics of their deposits showed the basins to be different, which additionally supports the hypothesis above supposed (Wierzbicki et al. 2007).

More diversified relief of the bottom of the Wierzchowo proglacial lake and the occurrence within its glaciolacustrine series of a greater number of lithofacies than within the Złocieniec deposits. Is also posible this suggests that the dynamics of depositional conditions in the Wierzchowo basin differed from that in the Złocieniec one, and the suggestion seems to be confirmed, among other things, by the presence of distinct traces of erosion structures within the glaciolacustrine series.

The Wierzchowo basin was probably nourished in a more ephemeral way than that near Złocieniec. The dynamics of depositional also processes displayed a marked variability during the particular deposition stages. This is evidenced both in syndepositional structures (a systematic change in the inclination of laminae, the presence of current structures and rounded clay pebbles) and erosional ones (a discordant arrangement of the successive lithofacies, the presence of a fossil form of the slope within older deposits).

\section{References}

Augustowski B., 1977. Pomorze. PWN, Warszawa.

BARTKOWSKI T., 1965. Rzeźba, budowa geologiczna, geomorfologia i stosunki wodne. Województwo koszalińskie. Monografia geograficzno-gospodarcza. Inst. Zachodni, Poznań.

BARTKOWSKI T., 1972. Strefa marginalna stadiału pomorskiego $\mathrm{w}$ aspekcie deglacjacji strefowej (na wybranych przykładach z pojezierzy: Drawskiego i Miastkowskiego na Pomorzu). Badania Fizjograficzne nad Polska Zachodnia XXV, A: 7-54.

GALON R., 1947. Podział Polski północnej na krainy naturalne. Czasopismo Geograficzne XVIII, 1-4: 113-122.

GALON R. \& ROSZKÓWNA L., 1967. Zasięgi zlodowaceń skandynawskich i ich stadiałów recesyjnych na obszarze Polski. In: Czwartorzęd polski. PWN, Warszawa: 18-38.

JANKOWSKA H., 1999. Cechy fizyczno-mechaniczne osadów ilastych wypetniajacych zbiornik zastoiskowy we wschodniej cześci Złocieńca na Pojezierzu Drawskim (stanowisko Złocieniec I). Maszynopis.

KARCZEWSKI A., 1985. Typy morfogenetyczne form strefy marginalnej fazy pomorskiej w obszarze tzw. lobu Parsęty na Pojezierzu Szczecinieckim. Sprawozdania PTPN 101: 29-32.

KARCZEWSKI A., 1994. Morpho- and lithogenetic diversification of the Pomeranian phase in western and central Pomerania. Z. Geomorph. N. F. Suppl. - Bd. Berlin - Stuttgart: 35-48.

KARCZEWSKI A., 1998. The North Pomeranian Baltic-facing slope as a privileged area for the formation of icedammed lakes. Quaestiones Geographicae 19/20: 51-56. 
KeILHACK K., 1901. Geologisch - morphologische Ubersichtskarte der Provinz Pommern, Masstab 1: 500 000. Kunigl. Preuss. Geol. Landesanst u. Bergakad., Berlin.

Keilhack K., 1930. Geologische Karte der Prowinz Pommern, 1: 500 000. Preus. Geol. Landesanst., Berlin.

KŁYsz P., 1990. Mechanizm kształtowania się strefy marginalnej fazy pomorskiej na obszarze Pojezierza Drawskiego. UAM, seria Geografia 47, Poznań.

KŁYsZ P., 1998. Zasięg ladolodu fazy pomorskiej na Pojezierzu Drawskim w świetle badań w rejonie Czaplinka, Żabina oraz Kalisza Pomorskiego. Rzeźba i osady czwartorzędowe obszarów wspótczesnego i plejstoceńskiego zlodowacenia pótkuli pótnocnej. Wydawnictwo Naukowe UAM, Poznań: 111-126.

Kondracki J., 1988. Geografia fizyczna Polski. Państwowe Wydawnictwo Naukowe, Warszawa.

KuBICKA A., 1995. Sposób sedymentacji iłów warwowych we wschodniej części zastoiska złocienieckiego. Maszynopis. Archiwum Wydziatu Nauk Geograficznych i Geologicznych Uniwersytetu im. Adama Mickiewicza, Poznań.

MAKSIAK S. \& Mróz W.J., 1978. Czwartorzęd środkowej części Pojezierza Pomorskiego (Sum.: Quaternary of the Central Part of the Pomeranian Lake District). Biuletyn Instytutu Geologicznego 300: 97-152.

MAYNE P.W., 2006. Interrelationships of DMT and CPTU readings in soft clays. Flat Dilatometer Testing (Proc. 2nd Intl.Conf. DMT), Washington, DC: 231-236.

MŁYNAREK Z. \& WierZBICKI J., 2007. Nowe możliwości i problemy interpretacyjne polowych badań gruntów. Geologos 11: 97-118.

PaluszKiewicz R., 2004. Warunki sedymentacji osadów rytmicznie warstwowanych $\mathrm{w}$ zastoisku złocienieckim na Pojezierzu Drawskim. (Sum.: Condition of sedimentation of rhytmically stratified deposits in the Złocieniec proglacial lake in the Drawsko Lakeland). PTPN, Wydz. Mat.-Przyr. Prace Komisji Geograficzno-Geologicznej 34. Poznań.

Paluszkiewicz Re., Paluszkiewicz Ry. \& Wierzbicki J., 2007. Analiza zmienności liotofacjalnej osadów zastoiska złocienieckiego w oparciu o wyniki sondowania statycznego. In: E. Smolska, D. Giriat (ed.), Rekonstrukcja dynamiki procesów geomorfologicznych-formy rzeźby i osady. Wydział Geografii i Studiów Regionalnych UW, Komitet Badań Czwartorzędu PAN, Warszawa: 427-438
Paluszkiewicz Re., Paluszkiewicz Ry. \& Wierzbicki J., 2009. Zastosowanie metody statycznego sondowania w analizie genezy osadów. Konferencja Geomorfologów Polskich "Metody badań w geomorfologii". Kielce: 126-127.

Paluszkiewicz Ry., 2008. Features of Pyrzyce glacilimnic reservoir deposits as a result of variable conditions of depositional environment. Wydawnictwo PTPN, Poznań.

PietKIEWIcz S., 1947. Podział morfologiczny Polski północnej i środkowej. Czasopismo Geograficzne XVIII, 1-4.

Polcyn J., 1995. Sedymentacja iłów warwowych zachodniej części zastoiska złocienieckiego w rejonie Darskowa na Pojezierzu Drawskim. Maszynopis. Archiwum Wydziału Nauk Geograficznych i Geologicznych Uniwersytetu im. Adama Mickiewicza, Poznań.

Rosa B. \& KozArski S., 1986. Przegladowa mapa geomorfologiczna Polski (arkusz Poznań) 1: 500 000. Instytut Geografii i Przestrzennego Zagospodarowania PAN.

TuszYŃSKA R., 1999. Cechy fizyczno-mechaniczne osadów ilastych wypełniających zbiornik zastoiskowy w zachodniej części Złocieńca na Pojezierzu Drawskim (stanowisko Złocieniec II). Maszynopis. Archiwum Wydziału Nauk Geograficznych i Geologicznych Uniwersytetu im. Adama Mickiewicza, Poznań.

Wilhelm A., 1999. Cechy fizyczno-mechaniczne osadów ilastych wypełniających zbiornik złocieniecki w rejonie Rzęśnicy koło Złocieńca. Maszynopis. Archiwum Wydziatu Nauk Geograficznych i Geologicznych Uniwersytetu im. Adama Mickiewicza, Poznań.

Wierzbicki J., Paluszkiewicz Re. \& Paluszkiewicz Ry., 2008. Wytrzymałość mechaniczna osadu a jego geneza na przykładzie wybranych utworów strefy marginalnej fazy pomorskiej zlodowacenia Wisły. Landform Analysis 9: 390-393.

Wierzbicki J., Paluszkiewicz Re. \& Paluszkiewicz Ry., 2011. The evolution of a Weichselian proglacial lake in NW Poland as revealed by static penetration tests. Geologos, 2011, 17 (2): 111-119. DOI: 10.2478/v10118-011-0007-4.

ZIELIŃSKI T., 1992. Kod litofacjalny - zapis podstawowych faktów litologicznych. In: Badania sedymentologiczne osadów czwartorzędowych. Letnia Szkoła Sedymentologiczna, Murzynowo k. Płocka: 297-301. 